\title{
PENGARUH ATRIBUT HOTEL BUTIK TERHADAP MINAT MENGINAP KEMBALI DENGAN KEPUASAN KONSUMEN SEBAGAI VARIABEL PERANTARA DI SURABAYA
}

\author{
Stephanie Hanjaya ${ }^{1}$, Michael David Pranata ${ }^{2}$, Fransisca Andreani ${ }^{3}$ \\ 1,2,3 Program Manajemen Perhotelan, Program Studi Manajemen, Fakultas Ekonomi, Universitas Kristen Petra \\ J1. Siwalankerto 121-131, Surabaya, Indonesia \\ Email: stephaniehanjaya96@gmail.com¹, michael_david30@yahoo.com², andrea@petra.ac.id ${ }^{3}$
}

\begin{abstract}
Abstrak
Studi ini bertujuan untuk mengamati pengaruh dari atribut hotel butik terhadap minat menginap kembali dengan kepuasan konsumen sebagai variabel perantara. Responden adalah 115 konsumen yang pernah menginap di hotel butik (Hotel Majapahit, Artotel, dan Town Square Hotel) di Surabaya dalam kurun waktu satu tahun terakhir. Data dikumpulkan menggunakan kuesioner dengan skala Likert dan dianalisa menggunakan metode PLS. Penelitian menunjukkan bahwa atribut hotel butik berpengaruh positif signifikan, baik terhadap kepuasan konsumen maupun minat menginap kembali. Meski demikian, kepuasan konsumen sebagai variabel perantara justru memiliki pengaruh kecil pada hubungan antara atribut hotel butik terhadap minat menginap kembali. Selain itu, hasil penelitian menunjukkan kepuasan konsumen bukan hal utama tetapi atribut hotel butik adalah hal terpenting yang menyebabkan konsumen mengunjungi hotel kembali.
\end{abstract}

Kata kunci: Hotel butik; atribut hotel;kepuasan konsumen; minat menginap kembali.

\begin{abstract}
This study is to observe the effects of boutique hotel attributes on revisit intention with customer satisfaction as a mediating variable. The study was conducted to 115 respondents who have stayed at boutique hotels (Majapahit Hotel, Artotel, and Town Square Hotel) in Surabaya in the past one year. Data were collected using questionnaires with a Likert scale and PLS method. The results show that boutique hotel attributes have positive significant effects on customer satisfaction and revisit intention. However, it is found that customer satisfaction as a mediating variable actually has a small effect on the relationship between boutique hotel attributes to revisit intention. This research shows that customer satisfaction is not the main reason, but boutique hotel attributes are the main elements of the hotel that determine customers to revisit boutique hotels.
\end{abstract}

Keywords: Hotel; hotel attributes; customer satisfaction; revisit intention.

\section{PENDAHULUAN}

Hotel butik mencerminkan bentuk akomodasi yang unik dan spesial, dengan tipe dekorasi modern, minimalis, atau mempunyai ciri khas, serta menyediakan berbagai amenities tambahan. Salah satu karakteristik yang unik dari butik hotel adalah jumlah kamar tidur yang sedikit (kurang dari 100 kamar), memiliki desain modern, memiliki layanan dengan fasilitas high-tech, atau adanya fitur-fitur pribadi, fitur sederhana, serta kualitas layanan yang istimewa (Goh, 2015). Hotel butik dirancang berdasarkan konsep untuk memenuhi harapan dan obsesi konsumen. Saat ini hotel tidak hanya mengandalkan kamar dan makan pagi sebagai bagian dalam strategi pemasaran, melainkan juga harus memiliki konsep yang unik (2014).

Survei pendahuluan dilakukan terhadap 10 konsumen yang pernah menginap di hotel butik di Surabaya untuk memperoleh kesan dan pengalaman menginap konsumen serta apakah konsumen berniat untuk menginap kembali di hotel butik. Pertanyaan yang diajukan sebanyak empat pertanyaan meliputi alasan memilih hotel tersebut, kesan yang diperoleh setelah menginap di hotel tersebut, apakah responden merasa puas menginap di hotel tersebut, dan apakah ada niat untuk mengunjungi atau menginap kembali di hotel yang sama. Dari hasil wawancara diketahui bahwa secara keseluruhan alasan dari responden dalam memilih untuk menginap di hotel butik karena adanya keunikan dari hotel, baik ditinjau dari nilai sejarah, desain interior serta perabot yang unik dimana hal ini merupakan ciri dari hotel butik. Alasan lain adalah terkait dengan atribut hotel secara umum seperti layanan, keramahan staf hotel, kualitas dan variasi makanan, dan fasilitas yang diberikan hotel. Dari hasil wawancara tersebut diketahui bahwa atribut dan ciri khas dari hotel butik membuat responden merasa puas dengan pengalaman menginap dan menimbulkan niat untuk menginap kembali di hotel butik.

Beberapa hotel butik yang ada di Surabaya adalah seperti Majapahit, Artotel, dan Town Square Hotel (Top 10 Boutique Hotel Surabaya, Charming 
Boutique Hotel Surabaya). Ketiga hotel ini termasuk hotel butik dengan ciri khas atau keunikan yang berbeda-beda dengan tingkat hunian tinggi dan kebanyakan tamunya adalah konsumen yang loyal. Oleh karena itu tujuan penelitian ini adalah untuk mengetahui: 1) pengaruh atribut hotel terhadap kepuasan konsumen, 2) pengaruh kepuasan konsumen terhadap minat menginap kembali, dan 3) pengaruh atribut hotel terhadap minat menginap kembali.

\section{TINJAUAN PUSTAKA}

\section{Boutique Hotel (Hotel Butik)}

Ahmad, Hemdi, dan Othman (2017) mendeskripsikan hotel butik sebagai kombinasi dari karakteristik layanan yang berkualitas, desain individual, lokasi dan fasilitas. Ciri dari hotel butik ditekankan pada pengalaman yang dirasakan oleh konsumen tentang tempat bersejarah serta identitas kebudayaan. Hotel butik memiliki 20-150 kamar dan bahkan ada juga yang sampai 200 kamar. Umumnya, hotel butik adalah hotel yang berbintang, memiliki restoran terkenal, dan berasal dari bangunan tua yang memiliki struktur unik yang telah dialihfungsikan dari bangunan asalnya.

Lebih lanjut Jones, Day, dan Felitti (2013) berpendapat bahwa international boutique hotel adalah hotel yang memiliki desain kontemporer dengan total jumlah kamar sampai dengan 100 ruangan yang memberikan layanan dengan tingkat personalisasi yang tinggi serta fasilitas modern. Desain dan keunikan hotel butik merupakan salah satu keunggulan untuk membedakan antara hotel tersebut dengan kompetitornya sehingga hotel dapat bersaing dengan hotel lainnya.

Beberapa fasilitas yang disediakan hotel butik adalah restoran, gym, sarana hiburan dan kolam renang. Fasilitas lain seperti airport shuttle bus dan layanan city tour juga merupakan sarana yang patut dipertimbangkan. Hal ini dikarenakan adanya perubahan gaya hidup, dan juga pertumbuhan kelas menengah di Indonesia. Fungsi hotel dari yang dulunya sekedar tempat menginap telah berubah menjadi tempat rekreasi (Aretta \& Hudrasyah, 2014).

\section{Atribut Boutique Hotel (Hotel Butik)}

Atribut adalah salah satu elemen yang mengarah pada identifikasi konsumen atas kemungkinan respons terhadap suatu kebutuhan. Baniya dan Thapa (2017) menguraikan bahwa atribut hotel memiliki peranan penting dalam mempengaruhi benak konsumen terutama saat menentukan memilih opsi akomodasi. Hotel yang memiliki atribut lebih unggul lebih mampu untuk memenangkan persaingan dengan jalan mempengaruhi semua aspek kritis yang menjadi bahan pertimbangan konsumen dalam memilih hotel.

Atribut hotel butik menurut Ahmad et al. (2017) meliputi:

1. Atribut fasilitas fisik adalah atribut yang diukur berdasarkan kamar hotel dan lobi. Fasilitas fisik diukur dengan indikator:

a. Ruangan kamar yang bernuansa historis dan atau mempunyai nilai seni.

b. Lobi hotel memiliki nilai dekorasi yang artistik dan atau bersejarah.

2. Atribut layanan adalah atribut yang diukur berdasarkan staf hotel dalam memberikan pelayanan.

Atribut layanan diukur berdasarkan indikator seragam yang digunakan staf mempunyai ciri khas unik yang membedakan dengan hotel lainnya.

3. Atribut kenyamanan adalah atribut yang diukur berdasarkan aksesibilitas dan lokasi yang strategis dari hotel. Atribut kenyamanan diukur menggunakan indikator:

a. Akses menuju hotel yang mudah dijangkau baik dengan kendaraan pribadi maupun umum.

b. Lokasi hotel strategis, misal terletak di jalan raya.

4. Atribut hotel image adalah atribut yang diukur berdasarkan desain dan tema dekorasi hotel. Atribut hotel image diukur menggunakan indikator:

a. Desain hotel yang mengandung unsur historis yang ditandai dengan adanya pajangan (lukisan/gambar/patung) dan dekorasi yang unik atau modern

b. Bentuk dan struktur bangunan hotel butik di Surabaya memiliki nilai seni dan atau historis

\section{Kepuasan Konsumen}

Kangogo, Musiega, dan Manyasi (2013) menjelaskan bahwa kepuasan konsumen merupakan perasaan puas dan senang yang muncul karena konsumen mendapatkan apa yang konsumen harapkan dari sebuah produk atau pelayanan. Penilaian konsumen dihasilkan dari harapan yang dimiliki konsumen dan pengalaman yang dirasakan saat menginap di hotel. Pengalaman ini dipengaruhi oleh interaksi personal antara pemberi layanan dengan konsumen saat menginap.

Kepuasan konsumen pada hotel membutuhkan banyak elemen. Beberapa diantaranya adalah suasana hotel dan keramahan fasilitas yang disediakan kepada konsumen. Kepuasan konsumen mempunyai efek positif pada keinginan konsumen untuk kembali ke hotel atau restoran tersebut (Kangogo et al., 2013).

Chun, Szu, Cheng, Te (2014) menguraikan bahwa kepuasan konsumen dapat diukur dengan dua indikator sebagai berikut: 
1. Perasaan konsumen (customer feelings).

Perasaan konsumen merupakan kondisi dimana konsumen merasa puas dengan apa yang diterima karena sesuai dengan harapan konsumen tersebut.

2. Kinerja yang diharapkan (Expected performance). Kinerja dari produk atau layanan diukur berdasarkan sejauh mana kinerja produk atau layanan dinilai profesional dan konsumen merasa nyaman ketika menggunakan produk atau layanan tersebut.

\section{Revisit Intention (Minat Menginap Kembali)}

Goh (2015) mendeskripsikan intention (minat) sebagai bentuk dari suatu perilaku. Dalam konteks hotel, intention merupakan perilaku yang mencerminkan keterikatan. Lebih jauh dijelaskan bahwa intention dalam industri perhotelan adalah revisit intention yang mencerminkan keinginan untuk tinggal kembali di hotel yang pernah dikunjungi ketika sedang melakukan perjalanan. Lebih lanjut Chun et al. (2014) menjelaskan bahwa revisit intention menunjukkan niat berkunjung kembali dan dapat diamati berdasar perilaku pembelian yang diharapkan

Ahmad et al. (2017) menjelaskan bahwa revisit intention merupakan salah satu bentuk behavioral intention yang merupakan keinginan yang direalisasikan dalam bentuk tindakan yang baik atau tidak baik. Tindakan yang baik adalah memberikan Word of Mouth yang positif untuk menggunakan layanan hotel tersebut, membayar harga yang lebih mahal untuk layanan premium dan menjadi konsumen setia. Sedangkan keinginan yang tidak baik adalah menyebarkan Word Of Mouth yang negatif, berhenti menggunakan layanan hotel tersebut, bahkan hingga mengambil tindakan hukum.

Menurut Chan (2018), ada 4 indikator yang dapat menimbulkan minat konsumen untuk menginap kembali (revisit intention), antara lain:

1. Intensi untuk menginap kembali di masa depan

2. Intensi untuk merekomendasikan kepada orang lain

3. Intensi untuk mengajak orang lain menginap di hotel butik

4. Merasa puas dan bersedia membagi cerita atau pengalaman menginap dengan orang lain.

\section{Hubungan antara Atribut Boutique Hotel (Hotel Butik) terhadap Kepuasan Konsumen}

Penelitian Baniya dan Thapa (2017) menunjukkan bahwa atribut hotel butik berpengaruh positif signifikan terhadap kepuasan konsumen. Atribut hotel yang diteliti adalah kualitas layanan, kualitas kamar, kualitas ruangan rekreasi, makanan, dan keamanan hotel. Atribut hotel dapat menciptakan pengalaman yang berkesan bagi konsumen. Hal inilah yang memicu timbulnya kepuasan konsumen.

Sedangkan hasil penelitian Usta, Berezina, dan Cobanoglu (2011) menunjukkan bahwa atribut hotel berpengaruh positif terhadap kepuasan konsumen. Beberapa atribut yang paling berpengaruh terhadap kepuasan konsumen di antaranya fasilitas yang diberikan, keramahan staf yang melayani, adanya bentuk layanan bebas parkir, serta berbagai bentuk acara hiburan yang diberikan. Atribut-atribut tersebut dapat meningkatkan kepuasan konsumen secara keseluruhan. Oleh karena itu hipotesa pertama dalam penelitian ini adalah:

H1: Atribut hotel berpengaruh positif dan signifikan terhadap kepuasan konsumen

\section{Hubungan antara Kepuasan Konsumen terhadap Revisit Intention (Minat Menginap Kembali)}

Penelitian Chan (2018) menjelaskan bahwa kepuasan konsumen berpengaruh positif dan signifikan terhadap revisit intention. Dalam penelitian ini revisit intention mewakili bentuk behavioral intention. Kepuasan konsumen berperan sebagai variabel perantara yang memperkuat hubungan antara atribut hotel terhadap revisit intention. Kepuasan konsumen merupakan dampak yang ditimbulkan dari pengalaman konsumen. Pengalaman konsumen ini dipengaruhi oleh berbagai macam faktor, salah satunya adalah interaksi konsumen dengan atribut hotel. Konsumen yang puas memiliki kecenderungan untuk datang berkunjung kembali.

Usta et al. (2011) juga mengemukakan hal serupa dimana kepuasan konsumen berpengaruh positif terhadap revisit intention. Dalam hal ini kepuasan merupakan variabel perantara yang dipengaruhi oleh atribut hotel. Atribut hotel yang diberikan dapat meningkatkan tingkat kepuasan yang menyeluruh bagi konsumen. Konsumen yang puas berniat untuk berkunjung kembali. Oleh karena itu hipotesa kedua dalam penelitian ini adalah:

H2: Kepuasan konsumen berpengaruh positif signifikan terhadap minat menginap kembali

\section{Hubungan antara Atribut Boutique Hotel (Hotel Butik) terhadap Revisit Intention (Minat Mengi- nap Kembali)}

Penelitian yang dilakukan oleh Ahmad, et al. (2017) menunjukkan bahwa atribut hotel mempengaruhi minat menginap kembali. Atribut hotel yang menarik berdampak pada konsumen. Konsumen akan terkesan dengan atribut yang disediakan oleh hotel dan hal ini akan memberikan pengalaman tersendiri yang membuat konsumen berniat untuk berkunjung kembali ke hotel butik. 
Usta et al. (2011) mengemukakan bahwa atribut hotel mempengaruhi revisit intention Salah satu atribut yang paling berpengaruh adalah fasilitas yang diberikan serta keramahan dari staf yang melayani. Atribut tersebut dapat meningkatkan keseluruhan kepuasan konsumen. Hal inilah yang membuat konsumen berkunjung kembali. Oleh karena itu hipotesa ketiga dalam penelitian ini adalah:

H3: Atribut Hotel berpengaruh positif signifikan terhadap minat menginap kembali.

\section{Model Penelitian}

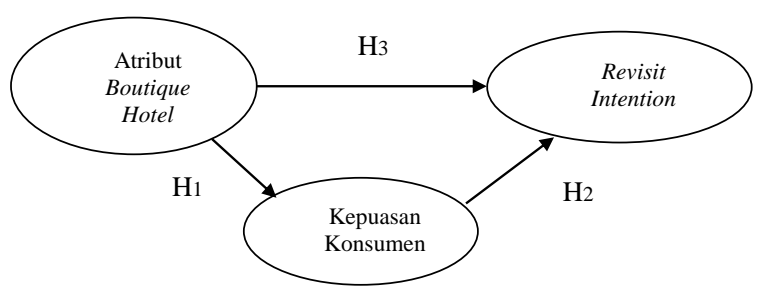

Gambar 1. Model Penelitian

\section{METODE PENELITIAN}

Metode penelitian yang digunakan adalah kuantitatif eksplanatif dimana data diukur dalam suatu skala numerik atau angka (Kuncoro, 2009). Penulisan eksplanatif bertujuan untuk menjelaskan hubungan antara dua atau lebih gejala atau variabel.

Judgmental sampling digunakan agar dapat menentukan responden berdasarkan kriteria yang paling sesuai dengan maksud dan tujuan penelitian (Malhotra, 2012, p. 375). Adapun kriteria sampel dalam penelitian ini adalah sebagai berikut:

1. Responden berusia di atas 21 tahun karena pada usia ini responden dianggap sudah memiliki penghasilan sendiri.

2. Pernah menginap di salah satu hotel butik di Surabaya dalam kurun waktu satu tahun terakhir (Oktober 2017 - November 2018).

Kuesioner menggunakan skala Likert dan disebarkan kepada 150 responden secara offline dalam kurun waktu 2 minggu di Surabaya. Setelah disortir ternyata kuesioner yang bisa diolah hanya 115 kuesioner saja. Lalu data diolah dan dianalisis dengan menggunakan Partial Least Square (PLS).

\section{HASIL PENELITIAN DAN PEMBAHASAN}

\section{Hasil Analisis Deskriptif}

Responden dalam penelitian ini kebanyakan pernah menginap di Hotel Majapahit (37 responden/ 32,1\%), Town Square Hotel (37 responden/ 32,1\%) dan Artotel (41 responden/ 35,6\%) yang terdiri dari 63 orang laki-laki $(54,7 \%)$ dan 52 orang perempuan $(45,2 \%)$. Sebagian besar berumur 18-25 tahun dengan jumlah sebanyak 39 orang $(33,9 \%)$ dengan tujuan berlibur 41 orang $(35,6 \%)$. Selain itu responden menginap di hotel butik dengan teman/ rekan kerja sebanyak 55 orang $(47,8 \%)$ dengan penghasilan di atas Rp 8.000.000,00 per bulan sebanyak 40 responden $(34,7 \%)$. Semua responden (100\%) berniat untuk menginap kembali di hotel

Hasil uji validitas dan reliabilitas menunjukkan bahwa seluruh indikator yang digunakan dalam penulisan ini dinyatakan valid dimana nilai Rhitung > Rtabel (0.361) dan reliabel dimana nilai Cronbach Alpha $>0.600$. Dengan demikian pernyataan dalam kuesioner dianggap akurat dalam menggambarkan indikator penelitian. Sedangkan perolehan mean untuk tiap indikator dapat dilihat pada tabel 1.

Pada tabel 1 dapat diketahui bahwa responden memiliki tingkat persetujuan yang tinggi terhadap atribut hotel butik, terutama pada X7 (mean 4,25). Responden berpendapat bahwa bentuk dan struktur bangunan hotel butik mempunyai nuansa historis, misalnya hotel Majapahit merupakan hotel peninggalan jaman Belanda dengan arsitektur yang unik. Artotel memiliki desain tangga di lobi yang dipenuhi lukisan coretan tangan dengan nilai seni yang tinggi. Town Square Hotel memiliki desain modern minimalis.

Selain itu konsumen juga mendapatkan pengalaman yang unik dengan layanan yang khas dari hotel butik sehingga konsumen merasa bahwa keputusan menginap di hotel butik merupakan keputusan yang tepat (mean $\mathrm{Y} 2=4,35$ ). Konsumen sangat setuju bahwa apa yang diterima dari hotel butik sudah sesuai dengan apa yang diharapkan konsumen. Lebih lanjut konsumen juga menyatakan kesediaannya untuk memberikan rekomendasi hotel butik kepada konsumen lain (mean $\mathrm{Z4}=4,32$ ).

\section{Analisis Outer Model}

Hasil uji validitas konvergen yang pertama menunjukkan bahwa nilai loading untuk indikator $\mathrm{X} 2$ adalah 0,477 dan X3 adalah 0.459 . Uji validitas konvergen memiliki syarat bahwa indikator harus memiliki nilai loading lebih besar dari 0,500. Oleh karena itu indikator X2 dan X3 dianggap tidak valid dan tidak digunakan dalam analisis selanjutnya sehingga diperoleh hasil seperti gambar 2 .

Sedangkan hasil uji reliabilitas diperoleh hasil seperti pada tabel 2 dimana semua variabel memiliki nilai composite reliability dan Cronbach's Alpha yang lebih besar dari 0,6 sehingga reliabel. 
Tabel 1. Hasil Perolehan Mean

\begin{tabular}{llll}
\hline & \multicolumn{1}{c}{ Indikator } & Mean & Kategori \\
\hline X1 & Kamar hotel butik bernuansa historis dan atau memiliki nilai seni. & 4,13 & Sangat Setuju \\
\hline X2 & Lobi hotel butik memiliki dekorasi bernuansa historis dan atau memiliki nilai seni. & 4,01 & Sangat Setuju \\
X3 & $\begin{array}{l}\text { Seragam yang digunakan oleh karyawan hotel butik memiliki ciri khas dan unik } \\
\text { yang membedakan dengan hotel lainnya. }\end{array}$ & 4,09 & Sangat Setuju \\
X4 & Akses menuju hotel butik mudah dijangkau baik dengan kendaraan pribadi & 4,10 & Sangat Setuju \\
& maupun umum. & 4,20 & Sangat Setuju \\
X5 & Lokasi hotel butik strategis dan terletak di jalan raya. & 4,07 & Sangat Setuju \\
X6 & Desain dan dekorasi hotel butik benuansa historis dan atau memiliki nilai seni. & Sangat Setuju \\
X7 & Bentuk dan struktur bangunan hotel butik bernuansa historis dan atau memiliki & $\mathbf{4 , 2 5}$ & Sangat \\
& nilai seni. & 4,33 & Sangat Setuju \\
Y1 & Saya mempunyai pengalaman yang menyenangkan selama tinggal di hotel butik. & $\mathbf{4 , 3 5}$ & Sangat Setuju \\
Y2 & Saya merasa bahwa keputusan untuk tinggal di hotel butik ini adalah tepat. & 4,26 & Sangat Setuju \\
Y3 & Saya merasa layanan yang diberikan hotel butik sesuai dengan keinginan & & \\
& konsumen. & 4,28 & Sangat Setuju \\
Y4 & Pelayanan yang diberikan hotel butik sangat profesional. & 4,33 & Sangat Setuju \\
Y5 & Pelayanan yang diberikan oleh hotel butik sangat unik. & 4,23 & Sangat Setuju \\
Z1 & Saya bersedia untuk menginap di hotel butik di masa yang akan datang. & 4,18 & Sangat Setuju \\
Z2 & Saya akan merekomendasikan hotel butik kepada orang lain. & 4,28 & Sangat Setuju \\
Z3 & Saya berniat untuk mengajak orang lain untuk menginap di hotel butik. & Sangat Setuju \\
Z4 & Saya bersedia membagi cerita terkait pengalaman menginap di hotel butik kepada & $\mathbf{4 , 3 2}$ & \\
& orang lain. & &
\end{tabular}

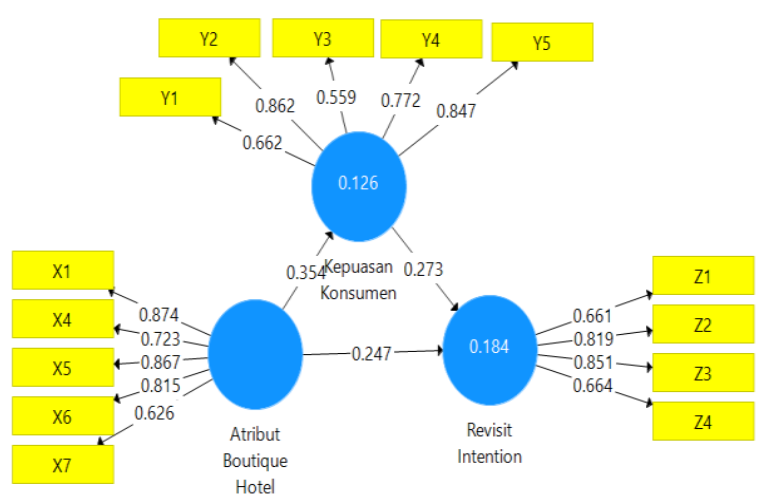

Gambar 2. Outer Model

Tabel 2. Hasil Uji Reliabilitas

\begin{tabular}{lccc}
\hline & $\begin{array}{c}\text { Cronbach's } \\
\text { Alpha }\end{array}$ & $\begin{array}{c}\text { Composite } \\
\text { Reliability }\end{array}$ & $\begin{array}{c}\text { Average } \\
\text { Variance } \\
\text { Extracted } \\
\text { (AVE) }\end{array}$ \\
\hline $\begin{array}{l}\text { Atribut Hotel } \\
\text { Butik }\end{array}$ & 0,857 & 0,889 & 0,619 \\
$\begin{array}{l}\text { Kepuasan } \\
\text { konsumen } \\
\text { Revisit Intention } \\
\text { Minat }\end{array}$ & 0,800 & 0,862 & 0,561 \\
$\begin{array}{l}\text { Menginap } \\
\text { Kembali) }\end{array}$ & & 0,839 & 0,568 \\
\hline
\end{tabular}

\section{Analisis Inner Model}

Analisis inner model dilakukan dengan bootstrapping dan diperoleh model sebagai berikut:

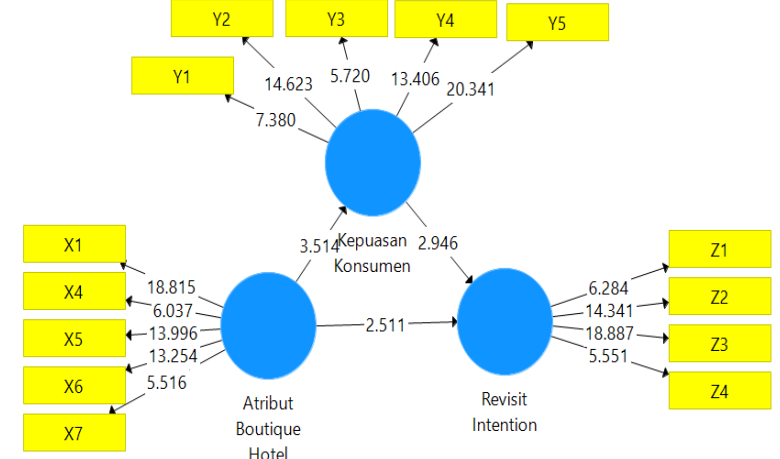

Gambar 3. Inner Model

\section{Pengaruh Langsung dan Tak Langsung}

Hasil koefisien Path, standard error dan Tstatistic dapat dilihat pada tabel 3 .

Pengaruh atribut hotel butik terhadap kepuasan konsumen menghasilkan $t$-statistic sebesar 3,409 > 1,960, maka H1 diterima. Koefisien path dari pengaruh atribut hotel butik terhadap kepuasan konsumen sebesar 0,354 menunjukkan bahwa pengaruh atribut hotel butik terhadap kepuasan konsumen adalah positif dan signifikan.

Kepuasan konsumen berpengaruh terhadap minat menginap kembali dengan t-statistic sebesar 3,236 $>1,960$, maka $\mathrm{H} 2$ diterima. Koefisien path dari pengaruh kepuasan konsumen terhadap minat menginap kembali sebesar 0,273 menunjukkan bahwa pengaruh kepuasan konsumen terhadap minat menginap kembali adalah positif dan signifikan. 
Tabel 3. Koefisien Path, Standart Error, dan T-Statistic

\begin{tabular}{clcccc}
\hline Hipotesis & \multicolumn{1}{c}{ Pengaruh Langsung } & Koefisien Path & Standard Error & T-Statistic Keterangan \\
\hline H1 & Atribut Hotel Butik $\rightarrow$ Kepuasan Konsumen & 0,354 & 0,104 & 3,409 & Signifikan \\
H2 & Kepuasan Konsumen $\rightarrow$ Minat Menginap Kembali & 0,273 & 0,084 & 3,236 & Signifikan \\
H3 & Atribut Hotel Butik $\rightarrow$ Minat Menginap Kembali & 0,247 & 0,104 & 2,374 & Signifikan \\
\hline
\end{tabular}

Tabel 4. Perbandingan Pengaruh Langsung dan Tidak Langsung

\begin{tabular}{llc}
\hline \multicolumn{1}{c}{ Pengaruh } & \multicolumn{1}{c}{ Jalur } & Koefisien Pengaruh \\
\hline Langsung & Atribut Hotel Butik $\rightarrow$ Minat Menginap Kembali & 0,247 \\
\hline Tidak & Atribut Hotel Butik $\rightarrow$ Kepuasan konsumen $\rightarrow$ Minat Menginap & 0,354 X 0,273 $=$ \\
Langsung & Kembali & 0,096442 \\
\hline
\end{tabular}

Pengaruh atribut hotel butik terhadap minat menginap kembali menghasilkan $t$-statistic sebesar 2,374 > 1,960, maka H3 diterima. Koefisien path dari pengaruh atribut hotel butik terhadap minat menginap kembali sebesar 0,247 menunjukkan bahwa pengaruh atribut hotel butik terhadap minat menginap kembali adalah positif dan signifikan.

Sedangkan pengaruh tidak langsung dapat dilihat pada tabel 4 . Tabel 4 menunjukkan besar pengaruh tidak langsung dari atribut hotel butik terhadap minat menginap kembali sebesar 0,096442 yang nilainya lebih kecil dari pengaruh langsung yaitu sebesar 0,247. Ini berarti variabel kepuasan konsumen memiliki pengaruh yang kecil terhadap atribut hotel butik dan minat menginap kembali Pada dasarnya ketika konsumen menginap di hotel, yang lebih penting bagi konsumen adalah atribut hotel yang ditawarkan. Bukan berarti kepuasan konsumen tidak penting, tetapi justru atribut hotel dapat meningkatkan kepuasan konsumen. Atribut hotel butik yang dimaksud adalah lobi yang nyaman, desain lobi dan kamar yang menarik dan atau lokasi hotel yang strategis. Dari profil responden dapat dilihat bahwa mayoritas alasan responden menginap di hotel butik adalah untuk berlibur, dimana konsumen yang berlibur menginginkan atribut hotel yang lebih menarik.

\section{Pembahasan}

Hasil penelitian menunjukkan bahwa atribut hotel butik berpengaruh positif signifikan terhadap kepuasan konsumen. Hasil yang diperoleh semakin menegaskan hasil penelitian dari Baniya dan Thapa (2017) dan Usta et al. (2011). Dalam hal ini atribut hotel butik semakin meningkatkan kepuasan konsumen. Atribut hotel butik membantu menciptakan pengalaman yang berkesan bagi konsumen. Hal inilah yang memicu timbulnya kepuasan konsumen.

Profil responden menunjukkan bahwa mayoritas responden menginap di hotel butik dengan tujuan berlibur bersama teman atau rekan kerja sehingga dapat disimpulkan bahwa konsumen yang menginap akan melihat atribut hotel butik terlebih dahulu sebelum memutuskan untuk menginap kembali. Hal ini dikarenakan konsumen merasa nyaman dengan lobi yang luas, akses yang mudah dijangkau, serta fasilitas yang ditawarkan hotel butik yang memadai.

Dari analisis statistik deskriptif dari variabel atribut hotel butik, dapat dilihat bahwa nilai mean tertinggi pada indikator yang menyatakan "Bentuk dan struktur bangunan hotel butik bernuansa historis dan atau memiliki nilai seni." Hal tersebut menunjukkan bahwa nilai historis dari hotel butik benar-benar tersampaikan kepada konsumen melalui bentuk dan struktur bangunan yang mempunyai ciri khas tersendiri. Pernyataan tersebut menggambarkan pengalaman yang dirasakan konsumen ketika menginap di hotel butik. Jika diamati, hotel Majapahit memiliki gedung dan struktur bangunan hotel yang merupakan peninggalan jaman Belanda sehingga memiliki nuansa historis yang kental. Sedangkan gedung dan struktur bangunan dari Artotel dan Town Square merupakan bangunan baru yang memiliki ciri khas unik dan mengandung nilai seni modern minimalis.

Konsumen mendapatkan nuansa yang berbeda saat menginap di hotel butik yaitu nuansa historis dan atau seni bila dibandingkan dengan hotel biasa. Pengalaman ini merupakan hal yang unik dan mampu menimbulkan rasa puas. Dari hasil analisis deskriptif pada variabel kepuasan konsumen, didapati bahwa indikator dengan nilai mean tertinggi adalah indikator yang menyatakan "Saya merasa bahwa keputusan untuk tinggal di hotel butik ini adalah tepat." Hal ini berarti bahwa konsumen merasa puas menginap di hotel butik. Nuansa historis dan atau berseni merupakan bentuk atribut yang unik dari hotel butik yang mampu memberikan kesan mendalam bagi konsumen dan memicu timbulnya kepuasan.

Hasil penelitian juga menunjukkan bahwa kepuasan konsumen berpengaruh positif dan signifikan terhadap minat menginap kembali. Semakin tinggi tingkat kepuasan yang dialami konsumen maka semakin tinggi pula minat konsumen untuk menginap 
kembali. Hasil yang diperoleh dalam penelitian ini sejalan dengan penelitian Usta, et al. (2011) dan Chan (2018).

Data penelitian juga menunjukkan bahwa semua responden bersedia untuk menginap kembali di hotel butik. Nilai mean tertinggi adalah pada indikator minat menginap kembali yang menyatakan "Saya bersedia membagi cerita terkait pengalaman menginap di hotel butik kepada orang lain". Hal ini berarti konsumen merasa puas dengan pengalaman yang diperoleh sehingga konsumen bersedia untuk menginap kembali dan bahkan membagikan pengalamannya kepada orang lain.

Lebih lanjut hasil penelitian menunjukkan bahwa atribut hotel butik berpengaruh positif dan signifikan terhadap minat menginap kembali. Hal ini sejalan dengan hasil penelitian Ahmad et al. (2017) dan Usta et al. (2011). Atribut hotel butik, yang menonjolkan nilai historis dan atau nilai seni, tidak hanya menimbulkan kepuasan konsumen namun juga secara langsung dapat mempengaruhi minat konsumen untuk menginap kembali. Nilai mean untuk indikator atribut hotel butik semuanya termasuk kategori sangat setuju. Ini menunjukkan bahwa atribut hotel butik memberikan kesan unik bagi konsumen. Kesan unik yang dialami konsumen akan memicu timbulnya minat menginap kembali.

Hasil penelitian menunjukkan bahwa pengaruh atribut hotel butik terhadap minat menginap kembali dengan kepuasan konsumen sebagai variabel perantara tidak terbukti signifikan. Penemuan ini berbeda dari hasil yang ditemukan dari penelitian Ahmad et al. (2017) dimana kepuasan konsumen dapat menjadi variabel perantara yang kuat terhadap minat menginap kembali. Hal ini disebabkan karena besar pengaruh tidak langsung dari atribut hotel butik terhadap minat menginap kembali lebih kecil daripada pengaruh langsungnya. Ketika konsumen menginap di hotel, hal utama yang lebih penting bagi konsumen adalah atribut hotel butik yang ditawarkan. Konsumen yang menginap di hotel butik dapat menikmati atribut hotel butik yang ditawarkan tanpa harus merasa puas terlebih dahulu.

Hasil analisis statistik deskriptif dari variabel atribut hotel butik menunjukkan nilai mean tertinggi pada indikator yang menyatakan "Bentuk dan struktur bangunan hotel butik bernuansa historis dan atau memiliki nilai seni." Ini berarti bahwa nilai historis dan atau nilai seni dari hotel butik benar-benar tersampaikan kepada konsumen melalui bentuk dan struktur bangunan sehingga membentuk kesan dan pengalaman yang mendalam pada konsumen.

Pengalaman ini merupakan hal yang unik dan mampu menimbulkan rasa puas. Indikator dengan nilai mean tertinggi adalah indikator yang menyata- kan "Saya merasa bahwa keputusan untuk tinggal di hotel butik ini adalah tepat." Nuansa historis dan atau nilai seni dari hotel butik mampu memberikan kesan mendalam dalam memberikan kepuasan konsumen.

Untuk variabel minat menginap kembali semuanya termasuk kategori sangat setuju yang berarti bahwa konsumen memiliki minat menginap kembali yang tinggi. Nilai mean tertinggi pada indikator yang menyatakan "Saya bersedia membagi cerita terkait pengalaman menginap di hotel butik kepada orang lain". Bentuk tindakan nyata dari konsumen yang memiliki minat menginap kembali adalah kesediaan konsumen untuk menceritakan pengalaman menginapnya kepada orang lain.

Hasil penelitian ini menunjukkan bahwa atribut hotel butik berpengaruh positif dan signifikan terhadap minat menginap kembali. Ini sesuai dengan hasil penelitian Ahmad et al. (2017) dan Usta et al. (2011). Atribut hotel butik tidak hanya menimbulkan kepuasan konsumen namun juga secara langsung dapat mempengaruhi minat menginap kembali. Atribut hotel termasuk kategori sangat setuju yang dapat memacu timbulnya minat konsumen untuk menginap kembali.

Pengaruh atribut hotel butik terhadap minat menginap kembalil dengan kepuasan konsumen sebagai variabel perantara tidak terbukti signifikan. Penemuan ini berbeda dari hasil penelitian Ahmad et al. (2017) dimana kepuasan konsumen dapat menjadi variabel perantara yang kuat terhadap minat menginap kembali. Hal ini disebabkan karena besar pengaruh tidak langsung dari atribut hotel butik terhadap minat menginap kembali lebih kecil daripada pengaruh langsungnya. Ketika konsumen menginap di hotel butik, hal utama yang lebih penting bagi konsumen adalah atribut hotel butik yang ditawarkan. Konsumen yang menginap di hotel butik dapat menikmati atribut hotel butik yang ditawarkan tanpa harus merasa puas terlebih dahulu.

\section{KESIMPULAN DAN SARAN}

Hipotesa pertama hingga ketiga dalam penelitian ini terbukti. Atribut hotel butik berpengaruh positif dan signifikan terhadap kepuasan konsumen. Kepuasan konsumen berpengaruh positif dan signifikan terhadap minat menginap kembali. Atribut hotel butik juga berpengaruh terhadap minat menginap kembali secara positif dan signifikan. Namun hipotesa keempat yang menyatakan kepuasan konsumen sebagai variabel perantara antara atribut hotel butik dan minat menginap kembali tidak terbukti kebenarannya.

Untuk penelitian selanjutnya, sebaiknya ditambahkan atribut hotel butik lain yang lebih dominan 
dengan menggunakan analisis faktor. Selain itu, nilai mean tertinggi ada pada nuansa historis dan atau nilai seni yang dimiliki hotel butik, maka sebaiknya hotel butik tetap menjaga nilai-nilai historis yang tercermin dari struktur bangunan ataupun nilai seni yang dimiliki atas desain dan struktur bangunan hotel. Hal ini bisa dilakukan dengan tetap memelihara struktur bangunan dan melakukan kegiatan renovasi rutin tanpa mengubah nilai historis dan atau nilai seni yang dimiliki, bukan hanya pada struktur bangunan saja tetapi juga desain kamar, lobi dan sebagainya.

\section{DAFTAR REFERENSI}

Ahmad, N. F., Hemdi, M. A., \& Othman, D. N. (2017). Boutique hotel attributes and guest behavioral intentions. Journal of Tourism, Hospitality \& Culinary Arts, 9(2), 257-266.

Aretta, D. D., \& Hudrasyah, H. (2014). Evaluating consumer's perceived value of urban boutique hotel uniqueness towards willingness to purchase intention case study: Artotel Jakarta. Journal of Business and Management,3(4), 447-455.

Baniya, R., \& Thapa, P. (2017). Hotel attributes infuencing international tourists' satisfaction and loyalty. Journal of Tourism and Hospitality Education, 7, 45-61.

Chan, S. (2018). Factor affecting revisit intention with customer satisfaction as a mediating variable in eco friendly resort. Jurnal Manajemen Dan Inovasi,9(1), 1-19.

Chun, C. H., Szu, W. Y., Cheng, Y. L., \& Te, P. C. (2014). The relationship among brand equity, customer satisfaction, and brand resonance to repurchase intention of cultural and creative industries in Taiwan. The International Journal of Organizational Innovation, 6(3), 106-120.

Goh, Y. N. (2015). Investigating revisit intentions for the boutique hotels of Penang-A UNESCO world heritage site. Asian Social Science, 11(4), 126-134.

Jones, D. L., Day, J., \& Quadri-Felitti, D. (2013). Emerging definitions of boutique and lifestyle hotels: A Delphi Study. Journal of Travel \& Tourism Marketing, 30(7), 715-731.

Kangogo, E. J., Musiega, \& Manyasi J. (2013). Effect of customer satisfaction on performance of the hotel industry in the western tourism circuit of Kenya. European Journal of Business and Management, 5(14), 87-99.

Kuncoro, M. (2009). Metode riset untuk bisnis \& ekonomi, edisi 3. Jakarta: Erlangga.

Malhotra, N. K. (2012). Basic marketing research: integration of social media. United State of America. Prentice Hall.

Top 10 Boutique Hotel Surabaya, Charming Boutique Hotel Surabaya. Retrieved June 18, 2018 from https://www.boutiquehotelsguides.com/ ?ufi2698521\&gclid=EAIaIQobChMI1YSU7pC4wIVEiUrCh147Q8gEAAYASAAEgLZKPD_ $\mathrm{BwE}$

Usta, M., Berezina, K., \& Cobanoglu, C. (2011). The impact of hotel attributes' satisfaction on overall guest satisfaction, Scholarworks@ @UMass Amherst. https://scholarworks.umass.edu/gradco nf_hospitality/2011/Presentation/5/ 